\title{
UIT HET DEPOT IN DE OPSTELLING: AZIATISCHE KERAMIEK IN HET PRINCESSEHOF LEEUWARDEN
}

De vernieuwde opstelling Aziatische keramiek in het Princessehof is bijna klaar. Nadat in 2002 vrijwel alle voorwerpen uit China, Japan, Thailand en Vietnam werden opgeborgen in het depot, werd er veel gefilosofeerd en nagedacht over een vernieuwde presentatie. Wim Crouwel werd gevraagd als ontwerper voor de vitrines. Hij maakte een nieuwe indeling van het gebouwencomplex, in samenspraak met de directeur en de conservatoren. De collectie Aziatische keramiek heeft een prachtige plek gekregen, namelijk op de eerste etage van het Paleis, de veel oudere Stins en het $19^{\mathbf{e}}$-eeuwse Pakhuis, de drie naast elkaar gelegen panden die samen het Princessehof vormen. In praktijk betekende dit dat er drie grote zalen beschikbaar kwamen, samen met twee kleinere ruimtes. Vijf museumzalen beschikbaar om de collectie Aziatische keramiek te tonen en vooral te laten schitteren. Een inspirerende en uitdagende klus voor de conservator!

\section{De collectie Aziatische keramiek: een inleiding}

Afbeelding 1

Pijlenvaas, onderglazuur blauw gedecoreerd porselein, H. $25 \mathrm{~cm}$, China, 1550-1600, inv.nr. NO 16, Bruikleen OttemaKingma Stichting

De vaas is beschilderd met Arabische teksten en was bestemd voor de islamitische markt.

De vorm werd ontleend aan metalen voorbeelden. In de gegoede bovenlaag was het een sport om volgens bepaalde regels pijlties te schieten die in de vaas terecht kwamen.

Objectfoto's bij dit artikel zijn van Johan van der Veer, voor Mu. seum het Princessehof
De opbouw en samenstelling van de collectie aziatica in Leeuwarden is onlosmakelijk verbonden met de naam van Nanne Ottema (1874-1955). ${ }^{1}$ Deze markante Fries was in het dagelijkse leven notaris in Leeuwarden maar daarnaast vooral een gepassioneerd verzamelaar. Ottema had - zoals de meeste $19^{\mathrm{e}}$-eeuwse verzamelaars - een brede belangstelling en bracht een groot aantal collecties bijeen; uiteenlopend van schilderijen, grafiek, zilver, meubels en textiel tot Friese volkskunst. Zijn grootste interesse ging echter uit naar keramiek, in het bijzonder naar Chinees porselein. In de loop van zijn leven zou hij hiervan een omvangrijke en waardevolle collectie samenstellen. In 1917 kreeg Ottema de beschikking over het voormalige stadspaleis van prinses Maria Louise van Hessen-Kassel (1688-1765) - het Princessehof waar hij een deel van zijn verzamelingen onderbracht. Zijn collectie was enkele jaren daarvoor, in 1910, aanzienlijk in omvang toegenomen toen hij de verzameling Indische kunst en kunstnijverheid van de Friese onderwijzer Anne Tjibbes van der Meulen (1862-1934) overnam. In 1926 werd ook de indrukwekkende verzameling Swatow-goed (Zhangzhou) van de mijningenieur Reinier Dirk Verbeek (1841-1926) aan Ottema's collectie toegevoegd. Samen vormen deze drie verzamelingen de kern van de collectie Aziatische keramiek van het Princessehof.

Bijna 38 jaar lang, van 1917 tot aan zijn dood in 1955, was Ottema directeur en conservator van het Princessehof. Van groot belang ten slotte is Ottema's omvangrijke bibliotheek, die hij parallel aan zijn kunstverzamelingen en met evenveel bezieling en kennis opbouwde. 


\section{Aard van de collectie}

Recentelijk verscheen het collectieplan van het Princessehof Leeuwarden. ${ }^{2}$ Om inzicht te krijgen in de samenstelling van de collectie Aziatische keramiek in het Princessehof, volgen hier enkele gegevens over deze collectie. Met een totale omvang van circa 14.000 inventarisnummers is de collectie Aziatische keramiek van het Princessehof Leeuwarden de grootste en tevens de veelzijdigste van Nederland. De collectie bestaat hoofdzakelijk uit Chinese keramiek (circa 13.000 nummers); daarnaast zijn er kleinere collecties keramiek uit Japan (800), Vietnam (130), Thailand (93), Korea (23) en Indonesië (60). ${ }^{3}$ De ambitie van het Princessehof wat betreft dit verzamelgebied is een gedetailleerd overzicht te bieden van de ontwikkeling van de Aziatische keramiek vanaf het vroege verleden tot heden in techniek, functie, vorm en versiering. ${ }^{4}$ Gezien de samenstelling van de collectie ligt het zwaartepunt vanzelfsprekend bij de Chinese productie en hierbinnen bij de keramiek die voor de export werd gemaakt, zowel voor Europa als voor Zuidoost-Azië.

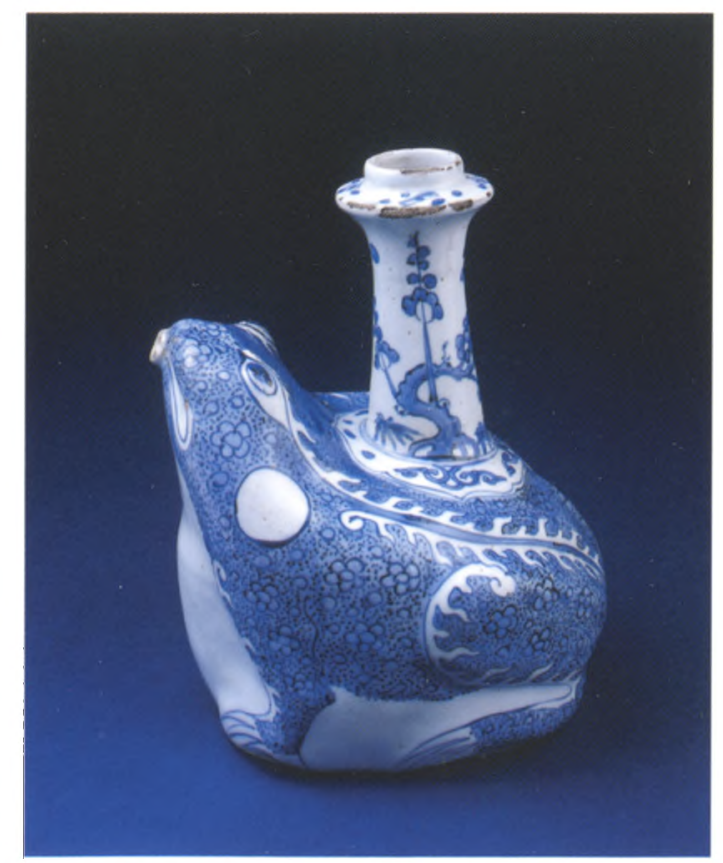

Afbeelding 2

Kendi, onderglazuur blauw gedecoreerd porselein, H. $18 \mathrm{~cm}$, China, 1590-1620, inv.nr. NO 1707, Bruikleen Ottema-Kingma Stichting

De kendi werd uitgevoerd in de vorm van een pad. Padden staan symbool voor lang leven. Chang-E stal het levenselixer van haar man er vluchtte hiermee naar de maan. Zij veranderde in een pad. Dergelijke kendis werden vanuit China geexporteerd naar het Midden-Oosten, Zuidoost-Aziê en Europa. Er werden ook andere dieren uitgekozen. In het scheepswrak De Witte Leeuw werd een kendi in de vorm van een olifant aangetroffen.

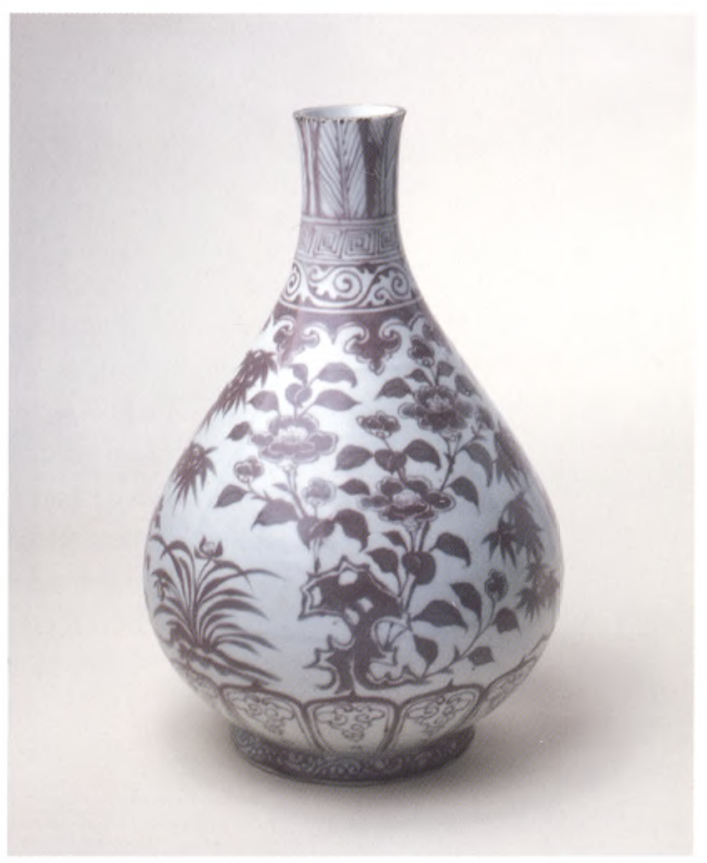

Afbeelding 3

Fles, koperrood gedecoreerd porselein, H. 31 cm, China, 1368-1398, inv.nr. OKS 1963-4, Bruikleen Ottema Kingma Stichting

Bij de beschildering van deze fles gebruikte men koperoxide als pigment om de rode kleur te verkrijgen. Het voorwerp dateert uit de tijd van keizer Hongwu. Deze techniek vereiste veel precisie. De kleur rood kon tijdens het bakken snel verkleuren in grijs of zwart, wanneer de tempertuur niet goed was of er teveel zuurstof in de oven kwam. Koperrood is in Nederlandse collecties zeer zeldzaam. 
In vergelijking met verschillende andere museale collecties is de Princessehofverzameling een zeer gevarieerde en vooral in de breedte opgebouwde collectie. ${ }^{5}$ Dit heeft alles te maken met de verzamelactiviteiten van Ottema. Bij het aanleggen van zijn collectie keek hij vooral naar de documentaire waarde van bepaalde stukken en was kwaliteit niet zijn enige criterium bij het wel of niet verwerven van een object.

In zijn Handboek verwoordde hij dit zelf als volgt: 'Het bijeenbrengen van een studie-collectie Chineesche ceramiek, die een zooveel mogelijk algemeen overzicht moest geven, doch waarbij de oud-Hollandsche belangen en het contract met den Indische archipel in de eerst plaats in het oog worden gehouden'. 6

\section{Sterke en zwakke kanten}

Vanwege Ottema's brede belangstelling kocht hij verzamelingen aan die door anderen werden gezien als minder interessant of zelfs minderwaardig. In zijn

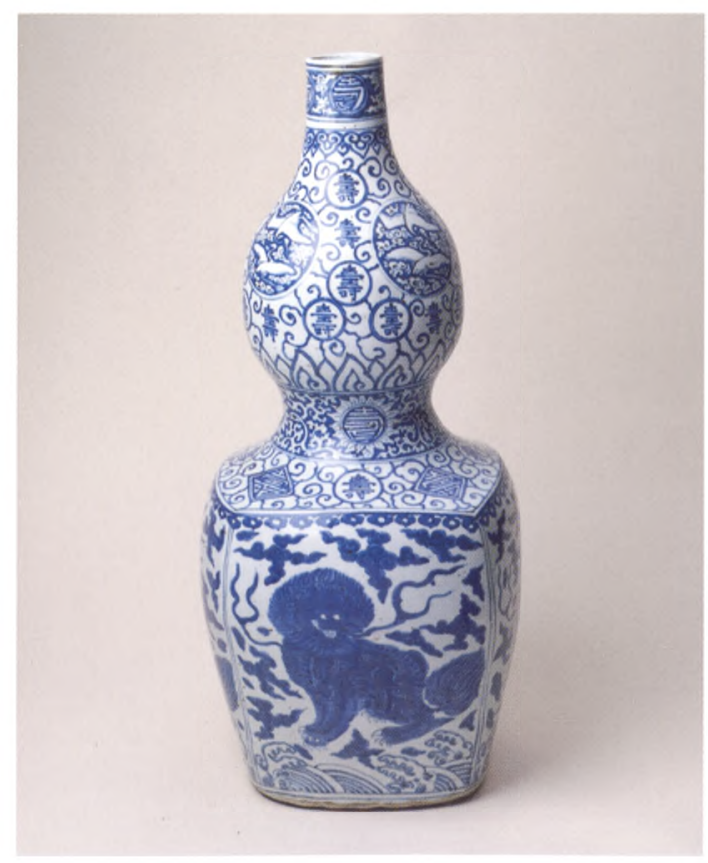

\section{Afbeelding 4}

Kalebasfles, onderglazuur blauw gedecoreerd porselein, $\mathrm{H} .63,5 \mathrm{~cm}$, China, ca. 1550, inv.nr. GMP 1967-111

De aangebrachte beschildering bestaat uit kraanvogels, een olifant en meerdere malen is het karakter shou aangebracht. Dit betekent lang leven.

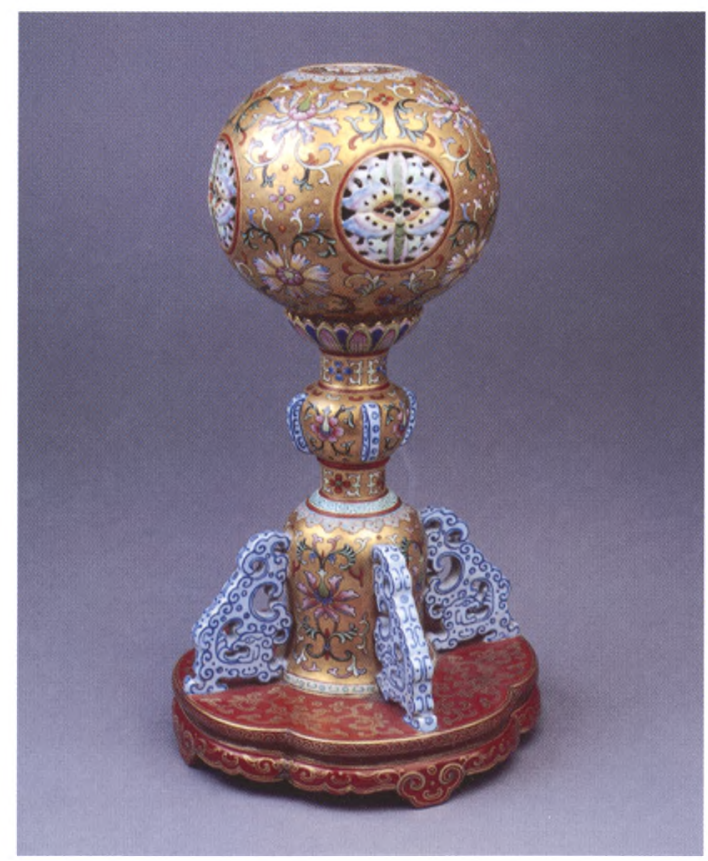

\section{Afbeelding 5}

Hoedenstandaard, H. $27,3 \mathrm{~cm}$, China, 1736-1795, Zegelmerk Qianlong, inv.nr. NO 435, Bruikleen Ottema-Kingma Stichting

De hoedenstandaard, guan jia of guan xun, heeft aan de bovenzijde een kleine platte deksel. De functie van het object bestond uit het verspreiden van de geur van gedroogde bloemblaadjes. De standaard is rijk en gedetailleerd beschilderd met een grote verscheidenheid in emailkleuren. Op de onderzijde is het zegelmerk Qianlong aangebracht. Naar alle waarschijnlijkheid werd de standaard vervaardigd voor het keizerlijk hof. De hoge kwaliteit en de formele manier van decoreren wijzen hieropa free access 


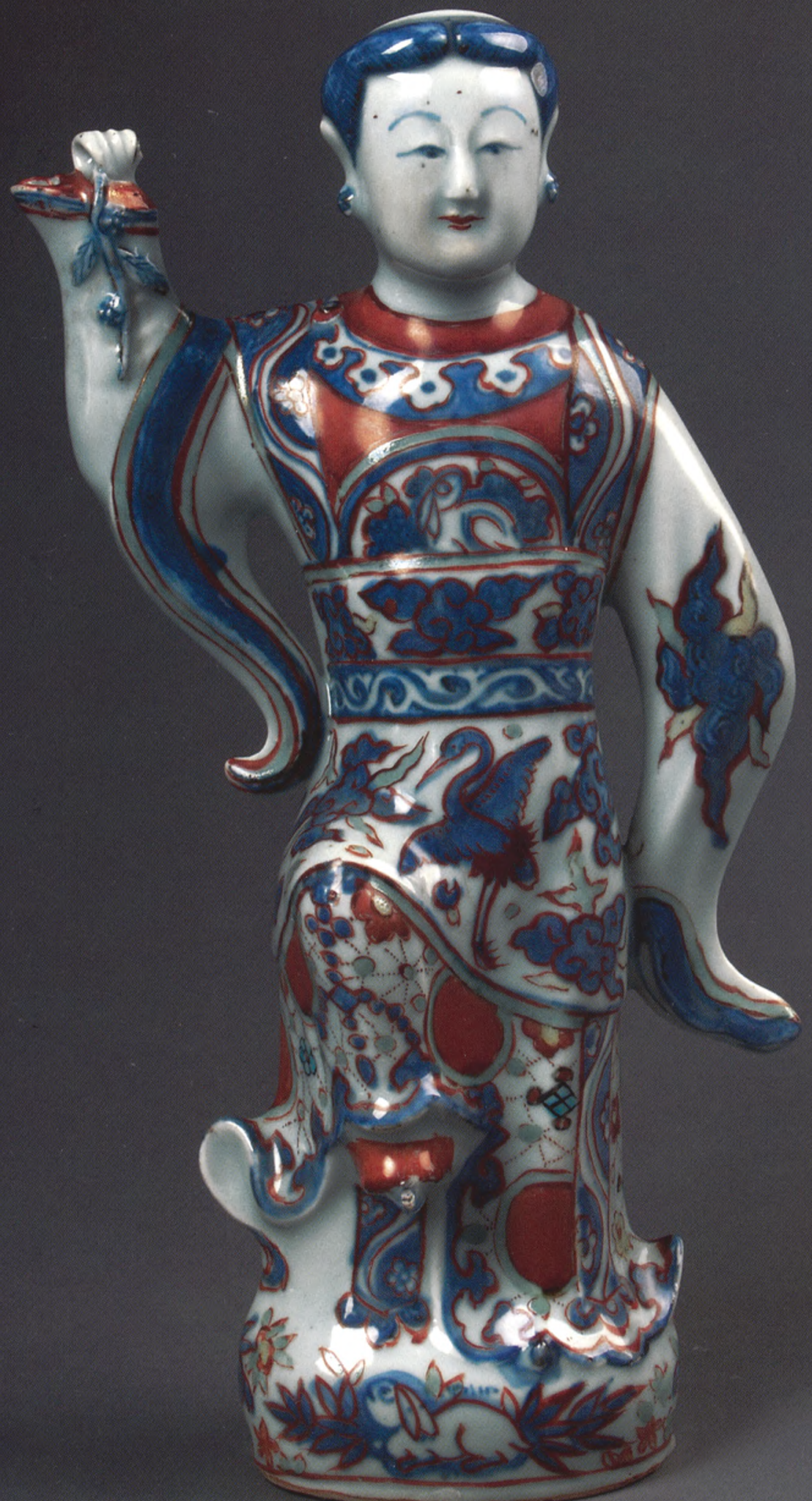




\section{Afbeelding 6}

Schenkkan in de vorm van een vrouwenfiguur, onderglazuur blauw gedecoreerd porselein met gekleurde emails, China, 1575-1600, Zegelmerk Shou, inv.nr. JMD-p. 2390, Bruikleen jan Menze van Diepen Stichting

De kan wordt gevuld door het gat in het hoofd, terwijl de tuit wordt gevormd door haar rechterarm. Op het hoofd hoorde corspronkelijk een haarknoet. Schenkkannen van dit type zijn uiterst zeldzaam. In de Wanliperiode werden voorbeelden gemaakt die zijn uitgevoerd in een onderglazuur blauwe beschildering. Het Princessehof heeft een voorbeeld uit deze periode. Deze bijzondere polychrome schenkkan is versierd met kraan. vogels en wolkmotieven. Op de voorkant van de voet is een haas geschilderd.
Handboek zette hij zich fel af tegen de term export-ceramiek. Hij vond deze term volledig misplaatst en schreef hierover het volgende: ' $(. .$.$) door alles wat$ niet valt onder de officieele en klassieke ceramiek te betitelen als exportceramiek en deze als een minderwaardige groep voor te stellen, die voor wilden en onbeschaafden zou zijn gemaakt'. ${ }^{7}$ Als voorbeelden van exportkeramiek noemt hij het kraakporselein en de grove porseleinen. Hij ging ver in zijn verontwaardiging en noemde deze benadering zelfs 'dom en hatelijk'. Bepaalde deelcollecties die nu wereldberoemd zijn zoals de Swatow-verzameling en de collectie martavanen werden vanuit een documentair uitgangspunt door Ottema aan de collectie toegevoegd. Ook de door hem bijeen gebrachte collectie vroeg-Ming porselein (1363-1644) geniet internationale bekendheid.

Deze grote diversiteit en de onderlinge variëteit vormen het uitgangspunt voor het inrichtingsplan voor de gehele eerste etage van het Princessehof Leeuwarden. In het collectieplan worden behalve de sterke kanten van de collectie ook de hiaten genoemd. Deze zijn op korte termijn niet door verwerving op te lossen. In het kader van de collectiemobiliteit werd een keuze gemaakt voor langdurige bruiklenen uit de collecties van andere musea. Bij de vernieuwde presentatie is dankbaar gebruik gemaakt van hier ontbrekende objecten uit de collecties van het Groninger Museum, het Gemeentemuseum Den Haag en uit de collectie van de Jan Menze van Diepen Stichting die wordt bewaard op de Fraeylemaborg in Slochteren.

\section{De nieuwe opstelling}

Om de bezoeker enige structuur te verschaffen in de bijna 5000 jaar Aziatische keramiekgeschiedenis is in de vernieuwde presentatie een aantal rode draden verweven. Door deze draden te combineren krijgt de bezoeker een breed en gevarieerd beeld van de getoonde keramiek.

\section{- CHRONOLOGIE}

De collectie omvat voorwerpen uit de prehistorie tot en met de periode rond 1900. Dit betekent dat bezoekers bijna 5000 jaar keramiekgeschiedenis kunnen volgen. De opstelling is chronologisch geordend.

\section{- TECHNIEK}

Tegelijk met de chronologie vinden voortdurend nieuwe technische ontwikkelingen plaats. Stooktechnieken, glazuursoorten, decoratietechnieken en vormontwikkeling zijn hierbij belangrijke ingrediënten. In de presentatie wordt de ontwikkeling getoond van zacht gebakken en koud beschilderd aardewerk naar harder gebakken en anders gedecoreerd steengoed om tenslotte te eindigen met kwalitatief hoogstaand porselein.

\section{- FUNCTIE}

Van een aantal objecten wordt de oorspronkelijke functie toegelicht in de bijschriften. Een prachtig geglazuurde pot krijgt uiteraard een andere betekenis wanneer blijkt dat het een grafgift was. Ook een waterdruppelaar krijgt extra betekenis wanneer bezoekers informatie krijgen over literaten.

\section{- SYMBOLIEK}

Op veel voorwerpen zijn symbolen of scènes geschilderd die zeker nję willekeurig zijn. Achter deze objecten schuilt een diepere betekenis die wordtree access 


\section{Afbeelding 7}

Bord, Amsterdams bont, $\varnothing 22 \mathrm{~cm}$, China, ca. 1730, inv.nr. LY 0592, Collectie Looxma Ypeij In de collectie Looxma Ypeij bevinden zich verschillende voorbeelden van Amsterdams bont. Behalve de reguliere voorbeelden zijn er ook verschillende afwijkende stukken. Een $17^{e}$-eeuwse klapmuts die in de $18^{e}$ eeuw werd overgedecoreerd is hiervan een voorbeeld. Ook dit bord waarop een oorlogsfregat met de vlag van de provincie Zeeland is geschilderd wijkt af. Op de achtersteven is het jaartal 1700 geschilderd. De vorm en de kwaliteit van de porselein wijzen echter op een datering rond 1730.

\section{Afbeelding 8 (pagina 21)} Plastiek van Guanyin, email sur biscuit, H. $18,5 \mathrm{~cm}$, China, ca. 1700, inv.nr. NO 1310, Bruikleen OttemaKingma Stichting

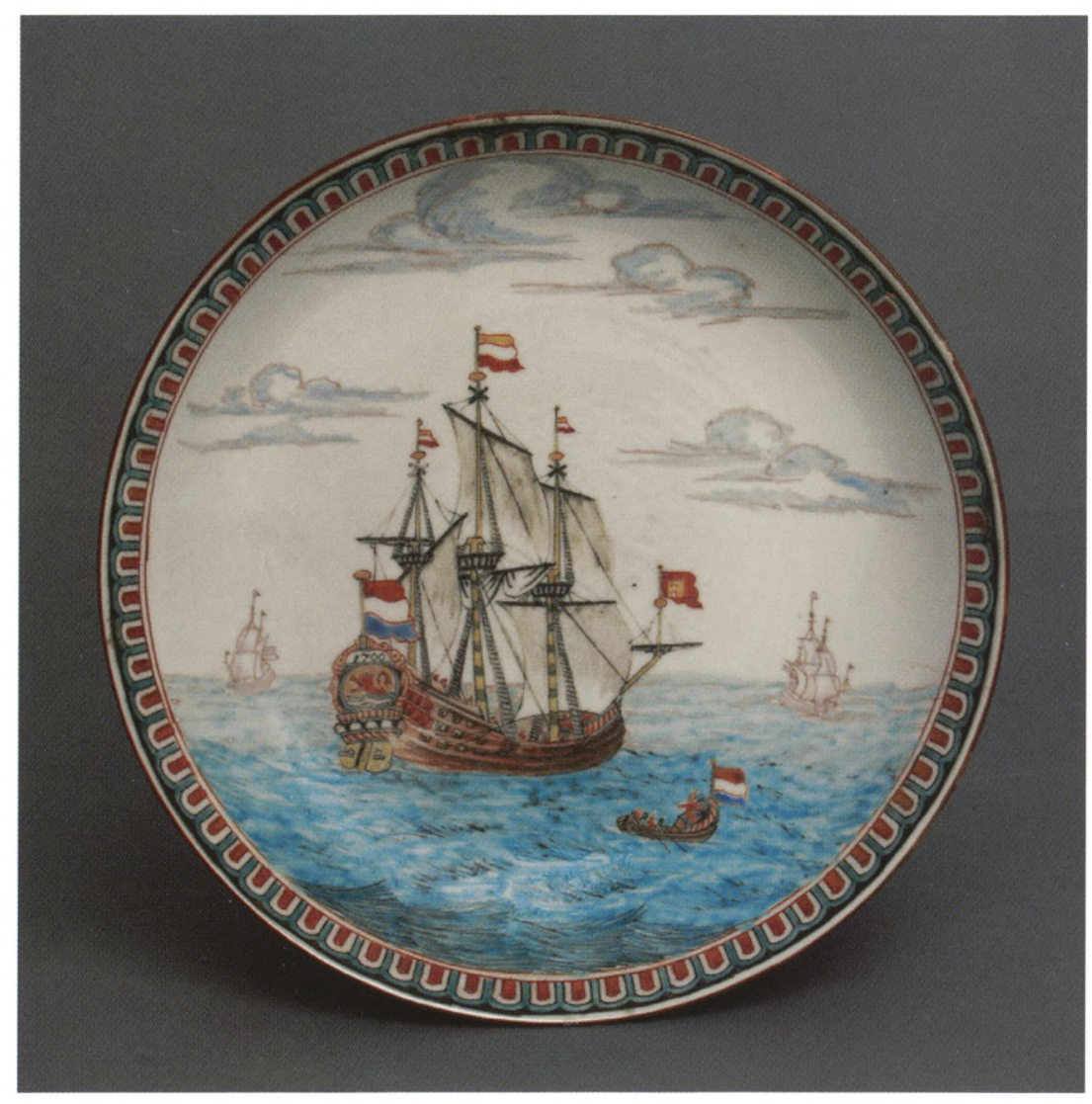

uitgelegd. Door deze uitleg wordt de bezoeker op de hoogte gebracht uit welke omgeving het voorwerp komt. Hiermee krijgen deze voorwerpen meer betekenis en identiteit en illustreren zij de eeuwenoude en rijke Chinese cultuur.

\section{De zalen}

\section{- de paleiszaAl}

In de Paleiszaal zijn vier wandvitrines aangebracht, terwijl vrij in de ruimte een grote vitrine en zes kleinere vitrines zijn geplaatst. Deze zaal toont de ontwikkeling vanaf de prehistorie met het koud beschilderde aardewerk tot en met het vroege Ming-porselein in koperrood en onderglazuur blauw.

De grote vitrine is gevuld met topstukken van groot formaat uit de Yuan- en Ming-dynastie. In de zes losse vitrines worden grafkeramiek, cizhou steengoed, Song-keramiek en illustratieve vormstukken van celadon en blauwwit en gekleurd Ming-porselein geëxposeerd.

\section{- DE GROTE STINSZAAL}

In deze ruimte zijn zeven grote vitrines vrij in de ruimte geplaatst, terwijl aan de wanden zes wandvitrines zijn aangebracht. De chronologie strekt zich uit van de late Ming- tot en met de Qing-dynastie.

In deze zaal wordt het kraakporselein uit de late Ming-periode getoond, een grote en zeer gevarieerde deelverzameling. Verder komen aan bod het $\mathrm{Over}_{\text {- }}$ : $11 \mathrm{Am}$ gangsgoed, het Kangxi-porselein, het famille verte, famille rose, het blancrde access 


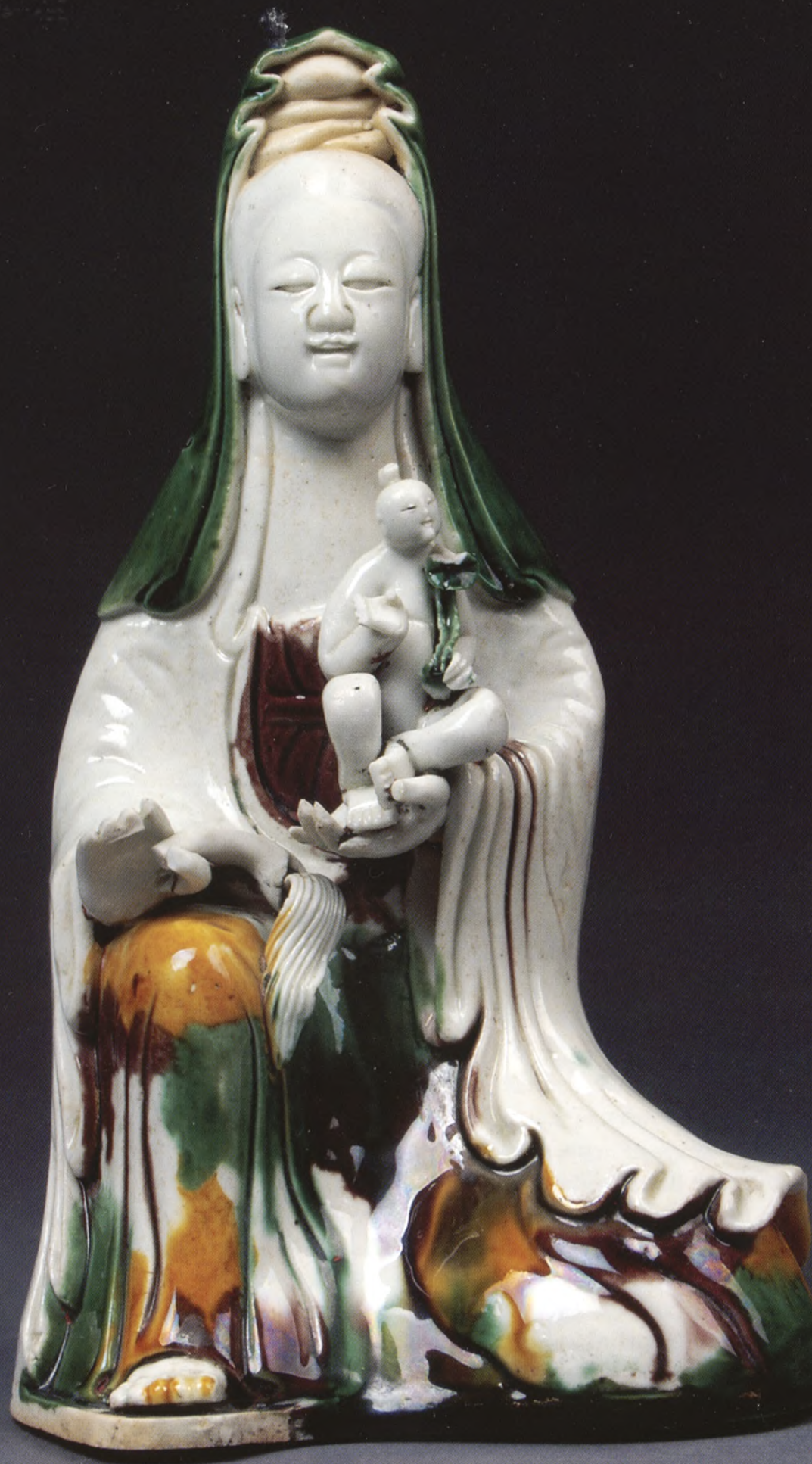




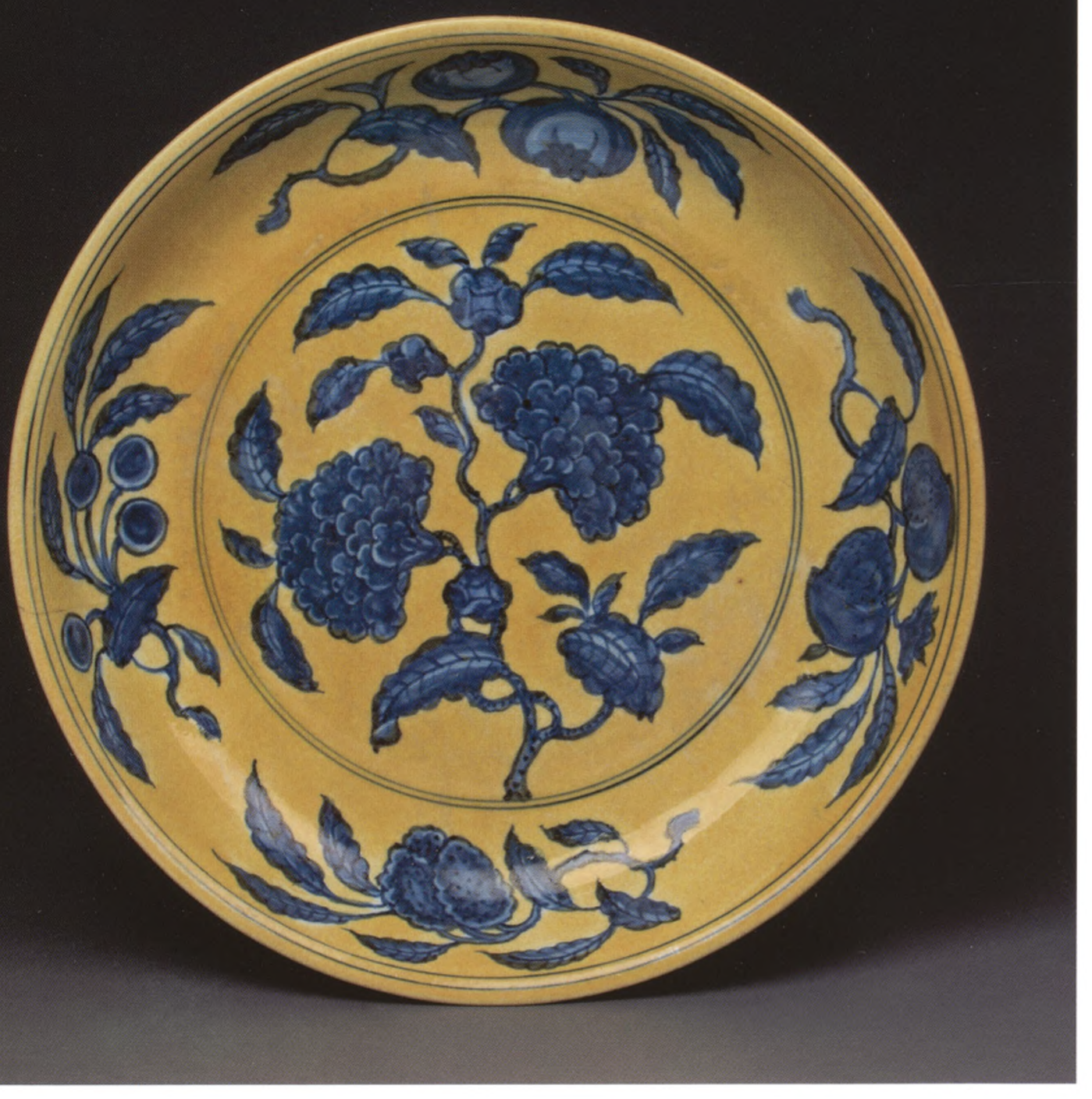

Chine en een gedeelte met monochromen. De collectie email sur biscuit en het Yixing-steengoed hebben hier een plaats gekregen, evenals de keramieksoorten uit de $19^{e}$ eeuw.

Ook in deze ruimte is de verzameling chronologisch gepresenteerd, maar kan men de collectie ook per onderwerp bekijken. Van de wandvitrines zijn er twee gevuld met kraakporselein, terwijl de andere vier bestemd zijn voor het Chine de commande. Hierin is een onderscheid gemaakt tussen porselein met Westerse voorstellingen en de keramiek waarvan de vorm oorspronkelijk uit Europa kwam.

\section{Drie Friese verzamelaars in het Princessehof Leeuwarden}

Het Princessehof Leeuwarden is een typisch werzamelaarmuseums/Het over: 41AM grote deel van de museumverzameling bestaat uit deelcollecties die $e^{v}$ đoofor ${ }^{2}$ access 
Afbeelding 9

Bord, onderglazuur

blauw en gele email,

D $29,5 \mathrm{~cm}$, China, 1506 1511, Zeskarakter merk

Zhengde, inv.nr. OCvo.

16.33, Bruikleen

Cemeentemuseum Den

Haag

Het uiterlijk van veel keizerlijk porselein uit de $16^{e}$ eeuw werd gebaseerd op producten uit de vroege $15^{e}$ eeuw. Dit patroon werd voor het eerst gemaakt in de tijd van keizer Xuande (1426-1435). Het patroon bleef populair tot aan het einde van de $16^{\circ}$ eeuw, in steeds wisselende uitvoeringen. gepassioneerde en bevlogen verzamelaars bijeen werden gebracht. In het vernieuwde Princessehof wordt ruim aandacht besteed aan deze collectioneurs en aan de bijzondere keramiekcollecties die zij verzamelden.

- Age Looxma Ypeij (1833-1892)

- Anne Tjibbes van der Meulen (1862-1934)

- Nanne Ottema (1874-1955)

De zeer vermogende Age Looxma Ypeij concentreerde zich vooral op de Aziatische handelskeramiek, bestemd voor de Westerse markt. In de vernieuwde presentatie wordt in januari 2007 een speciaal Looxma Ypeijkabinet ingericht, waarin duizenden stuks porselein worden getoond. De excentrieke en uit Bergum afkomstige onderwijzer Anne Tjibbes van der Meulen richtte zich op een geheel ander jachtterrein. ${ }^{8}$ In een tijd dat Europese verzamelaars geen enkel oog hadden voor de keramiek bestemd voor de Aziatische markt, verzamelde Van der Meulen op Java en Borneo grote voorraadpotten of martavanen. Hij werd hierin gestimuleerd door Nanne Ottema, die de volledige verzameling later van Van der Meulen zou overnemen. Verbeek legde een zeer omvangrijke collectie Swatow-keramiek aan, voor het overgrote deel bestaande uit grote in steengoed uitgevoerde schotels. Net als voor de martavanen geldt dat dankzij de verzamelactiviteiten van Verbeek en de scherpzinnigheid van Ottema het Princessehof beschikt over een collectie Swatow die wereldberoemd is en tegelijkertijd uniek is in het Westen.

\section{- DE KLEINE PALEISZAAL}

\section{MARTAVANEN EN SWATOW}

In de kleine Paleiszaal wordt een podiumopstelling gerealiseerd waarop zoveel mogelijk martavanen worden geplaatst. De variëteit in zowel de vormen als de formaten en de decoraties is groot. Ook de datering van de geëxposeerde voorbeelden bestrijkt een lange tijdsspanne. De vroegste martavanen dateren uit de late Tang-dynastie (618-907), terwijl de jongste voorbeelden dateren uit de periode rond 1900 . Martavanen zijn grote voorraadpotten die in China zijn vervaardigd voor de Aziatische markt. De naam is afgeleid van de havenstad Martaban in het zuiden van Birma. Hier werden martavanen vanaf de $14^{\mathrm{e}}$ eeuw gebruikt om gekonfijte vruchten in te bewaren. Naast deze functie, dienden ze ook om regenwater in op te vangen. Vooral in Indonesië vormden de oudere martavanen een kostbaar familiebezit, waarin zelfs de stoffelijke resten van voorouders bewaard werden. Hierdoor ontstond een sterke associatie met mystiek en voorouderverering.

De wanden in deze ruimte worden voorzien van grote hoeveelheden Swatowschotels die van plafond tot aan de vloer worden aangebracht. Ook hier zijn de hoeveelheden en de grote onderlinge variatie indrukwekkend. Uiteraard wordt in de verstrekte informatie ingegaan op de cultuurhistorische betekenis van dit soort schotels en de wijze waarop de collectie in de Princessehofverzameling kwam.

Swatow-keramiek ontleent zijn naam aan de Zuid-Chinese havenstad die tegenwoordig Shantou heet. Veel Swatow werd via deze stad verscheept naar Zuidoost-Azië, vooral naar de Filippijnen en Indonesië. In deze landen stond dit soort keramiek in hoog aanzien. Schalen en schotels waren kostbaar ree access 

familiebezit, waaraan magische en geneeskrachtige eigenschappen werden toegekend.

Het merendeel van het Swatow dateert uit de tweede helft van de $16^{\mathrm{e}}$ eeuw en de eerste helft van de $17^{\mathrm{e}}$ eeuw. Kenmerkend zijn de dikke scherf en de vlot geschilderde versieringen.

\section{- DE KLEINE STINSZAAL}

HET LOOXMA YPEIJ KABINET

Age Looxma Ypeij (1833-1892) was een eigenzinnige Friese 19e-eeuwer. Nooit getrouwd en een van de rijkste mensen van de provincie Friesland, bracht hij een veelzijdige en bijzonder omvangrijke verzameling bijeen. Het leeuwendeel van zijn verzameling bestond uit Aziatische keramiek. Looxma legateerde zijn collectie aan de provincie Friesland en liet dit legaat vergezeld gaan van een geldbedrag van vijftigduizend gulden.

In 1996 verdween deze opstelling uit de vaste presentatie van het verbouwde Fries Museum en werd de verzameling opgeslagen in het depot.

Deze omvangrijke en soms zelfs bij kenners onbekende porseleincollectie is in de afgelopen jaren beschreven door de conservatoren van het Princessehof. Deze ontsluiting is mede mogelijk dankzij een financiële ondersteuning van de Mondriaan Stichting. Het Aziatische deel van deze imponerende verzameling is te zien op de website www.aziatischekeramiek.nl. Deze site is een van de resultaten van het samenwerkingsverband tussen het Rijksmuseum, het Gemeentemuseum Den Haag, het Groninger Museum en het Princessehof Leeuwarden.

Dankzij de financiële ondersteuning van Friese fondsen is het mogelijk om een Looxma Ypeij-kabinet in een van de zalen aan te brengen. Met een knipoog naar het rijk gevulde porseleinkabinetten van weleer, maakt de bezoeker kennis met dit bijzondere fenomeen. De grote variëteit en de duizelingwekkende hoeveelheden porselein maken dit vertrek een lust voor het oog. In geen enkel ander Nederlands museum is een vergelijkbare presentatie te zien. Samen met de opstelling van de martavanen en de Swatow-borden zal het Looxma Ypeij-kabinet de presentatie van de Aziatische collecties in het Princessehof Leeuwarden afwisselender en gevarieerder maken. Door het accent te leggen op de Friese verzamelaars wordt ook de rijke traditie in het verzamelen van porselein in de provincie Friesland verklaard en in een cultuurhistorische context geplaatst.

\section{- DE PAKHUISZAAL}

\section{JAPAN, VIETNAM EN THAILAND}

In het voormalige Pakhuis is een zaal gereserveerd voor de collectieonderdelen uit Japan, Vietnam en Thailand. Uiteraard zijn deze collecties kleiner dan de verzameling keramiek die in China werd vervaardigd. In deze ruimte zijn zeven vitrines in een halve cirkel vrij in de ruimte geplaatst. Hierin zijn intussen de belangrijkste stukken Japans porselein opgesteld. De collectie van het Princessehof bestaat in hoofdzaak uit Japon de commande, maar kent ook stukken die voor de eigen Japanse markt werden gemaakt. In de vijf wandvitrines zullen de grotere stukken Japanse keramiek een plaats krijgen, samen met de kleinere maar kwalitatief zeer goede collectie Vietnamese keramiek. Ook de Thaise verzameling krijgt een plaats in de permanente per:41:41AM opstelling. Dankzij het bruikleen van de Vereniging van Vrienden dera free access 
Aziatische Kunst uit de verzameling van Professor G. Labroisse, kan een goede presentatie worden gerealiseerd. ${ }^{9}$

\section{Open depot}

Wanneer alle zalen op de eerste etage zijn ingericht, wordt het open depot gereed gemaakt voor het publiek. Het depot Aziatische keramiek wordt gevuld met de voorwerpen die geen deel uitmaken van de opstelling. De objecten worden per periode en/of stijl in de kasten geplaatst. Het ligt in de bedoeling om in deze ruimte ook studiemiddagen te laten plaatsvinden voor studenten en verzamelaars. Na een goede instructie zullen er ook hanteersessies worden georganiseerd.

Uiteraard hoop ik dat u naar het Princessehof Leeuwarden zult komen om de nieuwe presentatie te bekijken. Elke medewerker van een museum wil tenslotte dat er publiek komt! Ook Nanne Ottema wilde dit toen hij zijn verzamelde keramiek verwerkte tot museumopstellingen. In een tijd waarin bezoekersaantallen nog niet zo belangrijk waren als nu schreef hij in zijn hoofdstuk over keizerlijk porselein: 'Natuurlijk kan hier ook alleen een bezoek in het Museum zelf nadere opheldering geven. Alleen het bezien en betasten van deze documentaire stukken kan voldoende aanleiding geven tot vergelijk met eigen stukken en dateering en determineering daarvan' ${ }^{10}$

\section{Noten}

1. S. Bak (red.), Nanne Ottema. Een kleurrijk verzamelaar, Franeker, 1999.

2. Collectieplan 2010 Princessehof Leeuwarden - Nationaal Keramiekmuseum, Leeuwarden, 2006.

3. Dit is inclusief de collectie Looxma Ypeij

4. Toekomstvisie 2010 Princessehof Leeuwarden - Nationaal Keramiekmuseum, Leeuwarden, 2002, p. 33.

5. Collectieplan 2010 , p. 30

6. Nanne Ottema, Chineesche ceramiek, Handboek naar aanleiding van de verzamelingen in Museum het Princessehof, Amsterdam, 1946, p. 7.

7. Nanne Ottema, Chineesche ceramiek. Handboek naar aanleiding van de verzamelingen in Museum het Princessehof, Amsterdam, 1946, p. 16.

8. S. Bak (red.), Nanne Ottema. Een kleurrijk verzamelaar, Franeker, 1999, pp. 33-41.

9. M. Karatas, 'Een bijzondere herinnering aan Indonesië. De collectie Labroisse', Keramika 2003 (2), pp. 21-25.

10. Nanne Ottema, Chineesche ceramiek. Handboek naar aanleiding van de verzamelingen in Museum het Princessehof, Amsterdam, 1946, p. 244 